\title{
PELATIHAN PEMBUATAN DESAIN PROTOTIPE APLIKASI MENGGUNAKAN PROTO IO UNTUK MENUMBUHKAN MINAT PEMBELAJARAN PEMROGRAMAN di SMK NASIONAL MALANG
}

\author{
Lia Farokhah $^{1 *}$, Fadli Almu'ini Ahda², Suastika Yulia Riska ${ }^{3}$ \\ ${ }^{1 *}$ Program Studi Teknik Informatika, STMIK ASIA Malang \\ ${ }^{2}$ Program Studi Teknik Informatika, STMIK ASIA Malang \\ ${ }^{3}$ Program Studi Teknik Informatika, STMIK ASIA Malang \\ ${ }^{*}$ Corresponding author \\ E-mail : farokhah@asia.ac.id
}

Diterima 2 Agustus 2019, Disetujui 20 Agustus 2019

\begin{abstract}
ABSTRAK
Mata pelajaran pemrograman merupakan salah satu mata kuliah kosentrasi atau jurusan di Sekolah Menengah Kejuruan (SMK) atau perguruan tinggi berbasis komputer. Mata kuliah pemrograman menjadi salah satu kesulitan yang dihadapi siswa-siswi maupun mahasiswa dalam menempuh pembelajaran sesuai kosentrasi atau jurusan mereka. Hal ini sangat kontradiksi dengan jurusan yang mereka ambil sehingga perlu di ujicoba pengembangan pedagogi pengajaran untuk menunjang motivasi belajar dalam pemrograman. Pengembangan pembelajaran menjadi sangat penting karena selain kita berada pada abad teknologi yang membutuhkan lebih banyak aplikasi yang harus dikembangan untuk membantu kehidupan manusia. Pengembangan pedagogi pengajaran juga digunakan untuk menumbuhkan motivasi belajar pemrograman agar siswa-siswi atau mahasiswa dengan jurusan atau kosentrasi computer bisa menyukai mata pelajaran pemrograman dimana pada akhirnya menunjang kualitas lulusan yang dihasilkan sesuai bidangnya. Dalam pengembangan pedagogi pada pengabdian masyarakat yang dilakukan di SMK Nasional Malang dilakukan dengan melakukan pre test pertanyaan kuesioner sebelum dan sesudah diadakannya pelatihan pembuatan prototipe aplikasi menggunakan software instan PROTO IO. Hasil yang didapat dari analisis kuesioner didapatkan peningkatan motivasi belajar pemrograman sebesar $76,67 \%$ dan peningkatan motivasi minat menjadi programmer sebesar $16,66 \%$.
\end{abstract}

Kata kunci: pedagogi, pemrograman, motivasi belajar, aplikasi

\section{ABSTRACT}

Programming lesson is one of the concentration courses or majors in Vocational Schools (SMK) or computer-based colleges. Programming lesson become one of the difficulties faced by students according to their concentration or their majors. This is very contradictory with their majors so that it is necessary to test the development of teaching pedagogy to support learning motivation in programming lesson. The development of learning is very important because besides we are in the technology era that requires more applications that must be developed to help human life. The development of teaching pedagogy is also used to foster motivation to learn programming lesson so students with majors or concentrations of computers can like programming lesson which ultimately support the quality of graduates produced in their fields. In the development of pedagogy on society service carried out in SMK Nasional Malang, questionnaire were conducted before and after the training on making prototype applications using PROTO IO with instant software. The results obtained from questionnaire showed that an increase in programming learning motivation with $76.67 \%$ and an increase in motivation to become a programmer of $16.66 \%$.

Keywords: pedagogy, programming, learning motivation, application

PENDAHULUAN

Dosen merupakan pendidik

profesional dan ilmuwan dengan tugas utama mentransformasikan, mengembangkan, dan menyebarluaskan Ilmu Pengetahuan dan
Teknologi melalui Pendidikan, Penelitian, dan Pengabdian kepada Masyarakat. Tugas utama dosen dirangkum dalam Tridharma Perguruan Tinggi (KEMENRISTEKDIKTI, 2017). Tridharma Perguruan Tinggi merupakan 
kewajiban Perguruan Tinggi untuk menyelenggarakan Pendidikan, penelitian, dan pengabdian kepada masyarakat (KEMENRISTEKDIKTI, 2017).

STMIK ASIA Malang merupakan salah satu perguruan tinggi swasta dengan fokus ilmu komputer di Jawa Timur. Dalam menjalankan Tridharma perguruan tinggi, Lembaga Penelitian dan Pengabdian kepada Masyarakat (LPPM) STMIK ASIA Malang mewajibkan setiap dosen untuk melakukan pengabdian kepada masyarakat (Pengmas) setiap semester. Adapun tujuan yang ingin dicapai adalah mendekatkan diri kepada masyarakat dan mengimplementasikan keilmuan kepada masyarakat. LPPM mengharapkan setiap dosen bisa mengimplementasikan keilmuan terutama hasil penelitian kepada masyarakat. Adapun objek yang diambil bisa berupa masyarakat desa, sekolah, kelompok atau komunitas.

SMK Nasional Malang merupakan salah satu objek pengabdian yang sudah melakukan kerjasama dengan perguruan tinggi STMIK ASIA Malang. Dalam pelaksanaan pengabdian, Dosen pengabdi ingin menguji siswa-siswi SMK Nasional jurusan rekayasa perangkat lunak (RPL) dalam pembelajaran mata pelajaran pemrograman. Selama ini, Minat dan motivasi belajar mata pelajaran masih jauh dari target yang ditetapkan oleh guru SMK Nasional. Siswa-siswi cenderung memandang mata pelajaran pemrograman sebagai hal yang sangat sulit untuk disukai. Hal ini hampir sama dengan pola pikir yang ada pada mahasiswa komputer semester awal di perguruan tinggi STMIK ASIA Malang. Pola pikir ini sangat kontradiksi dengan jurusan yang mereka ambil sehingga perlu di ujicoba pengembangan pedagogi pengajaran untuk menunjang motivasi belajar dalam pemrograman.

Pengembangan pedagogi yang dilakukan adalah dengan memanfaatkan software desain prototipe PROTO IO dalam Menumbuhkan Minat Pembelajaran Pemrograman di SMK Nasional Malang. Strategi yang diambil adalah dengan membuat siswa-siswi tertarik melalui aplikasi prototipe PROTO IO yang akan membuat desain sebuah website atau aplikasi android dengan dinamis sehingga pada akhirnya siswa-siswi ingin memperdalam dan menumbuhkan minat untuk menjadikan aplikasi yang dirancang benar-benar siap pakai.

Berdasarkan paparan latar belakang diatas, akan dilakukan pengujian melalui kuesioner dalam pre test yaitu sebelum pelatihan dan post test yaitu setelah pelatihan dilakukan. Hal ini ditujukan untuk mengetahui perubahan minat dan pola pikir yang ada pada siswa-siswi SMK Nasional dalam memandang mata pelajaran pemrograman.

\section{HASIL DAN PEMBAHASAN \\ Pengujian Kuesioner \\ Angket Penilaian Sebelum Pelatihan}

Dalam implementasi pedagogi untuk meningkatkan minat siswa-siswi pada mata pelajaran pemrograman di SMK Nasional Malang, metode yang digunakan adalah pengujian hasil pelatihan dengan pre test sebelum pengabdian dan setelah pengebdian melalui kuesioner. Hal ini dilakukan untuk mendapatkan hasil evalusi yang diinginkan. Adapun pertanyaan pre test dan post test yang diajukan didetailkan pada tabel 1 dan tabel 2 .

Tabel 1. Pertanyaan Pre-Test

\begin{tabular}{|c|l|}
\hline No & \multicolumn{1}{|c|}{ Pertanyaan Pre Test } \\
\hline 1 & $\begin{array}{l}\text { Apakah anda menyukai mata pelajaran } \\
\text { pemrograman? }\end{array}$ \\
\hline 2 & $\begin{array}{l}\text { Apakah mata pelajaran pemrograman } \\
\text { mudah bagi anda? }\end{array}$ \\
\hline 3 & $\begin{array}{l}\text { Apakah bagi anda mudah dalam } \\
\text { membuat sebuah aplikasi? }\end{array}$ \\
\hline 4 & $\begin{array}{l}\text { Apakah anda mempunyai keinginan } \\
\text { menjadi seorang programmer? }\end{array}$ \\
\hline 5 & $\begin{array}{l}\text { Apakah anda mengetahui ada banyak } \\
\text { aplikasi instan di internet untuk } \\
\text { membuat prototipe suatu aplikasi? } \\
\text { (Contoh: Marvel, Mock up, Wix.com, } \\
\text { Pixate, Facebook Origami, Framer } \\
\text { Studio, Proto io, Adobe XD) }\end{array}$ \\
\hline 6 & $\begin{array}{l}\text { Apakah anda pernah membuat prototipe } \\
\text { aplikasi? (Menggunakan Media offline } \\
\text { maupun online dihitung) }\end{array}$ \\
\hline 7 & $\begin{array}{l}\text { Apakah anda pernah membuat prototipe } \\
\text { aplikasi dengan aplikasi instan yang } \\
\text { tersedia di internet? }\end{array}$ \\
\hline
\end{tabular}

Pertanyaan pre test yang digunakan untuk mengetahui kondisi awal dari pola fikir dan pandangan dari siswa-siswi SMK Nasional Malang Jurusan Rekayasa Perangkat Lunak terhadap pelajaran pemrograman dan dunia programmer.

\section{Angket Penilaian Setelah Pelatihan}

Tabel 2. Pertanyaan Post Test

\begin{tabular}{|c|l|}
\hline No & \multicolumn{1}{|c|}{ Pertanyaan Post Test } \\
\hline 1 & $\begin{array}{l}\text { Apakah pelatihan yang diberikan } \\
\text { berguna bagi anda? }\end{array}$ \\
\hline 2 & $\begin{array}{l}\text { Apakah pelatihan yang diberikan } \\
\text { memberikan dampak bagi anda? }\end{array}$ \\
\hline
\end{tabular}




\begin{tabular}{|c|l|}
\hline 3 & $\begin{array}{l}\text { Apakah materi pelatihan yang diberikan } \\
\text { mudah bagi anda? }\end{array}$ \\
\hline 4 & $\begin{array}{l}\text { Apakah materi pelatihan yang diberikan } \\
\text { menarik bagi anda? }\end{array}$ \\
\hline 5 & $\begin{array}{l}\text { Apakah tampilan user interface pada } \\
\text { prototipe menggunakan aplikasi instan } \\
\text { (contoh: menggunakan proto io) menarik } \\
\text { bagi anda? }\end{array}$ \\
\hline 6 & $\begin{array}{l}\text { Apakah dengan membuat prototipe } \\
\text { melalui aplikasi instan (contoh: Proto lo) } \\
\text { membuat anda ingin membuat aplikasi } \\
\text { tersebut benar-benar berfungsi (aplikasi } \\
\text { yang dibuat melalui Proto lo hanya } \\
\text { desain interface aplikasi namun belum } \\
\text { berfungsi secara pemrograman) }\end{array}$ \\
\hline 7 & $\begin{array}{l}\text { Apakah anda ingin belajar pemrograman } \\
\text { untuk bisa membuat prototipe yang } \\
\text { dibuat benar-benar berfungsi? }\end{array}$ \\
\hline 8 & $\begin{array}{l}\text { Apakah anda mempunyai keinginan } \\
\text { menjadi seorang programmer? }\end{array}$ \\
\hline
\end{tabular}

Pertanyaan post test yang diajukan setelah pelatihan di tujukan untuk mengetahui menfaat metode pedagogi pelatihan, pandangan serta minat dalam menjadi seorang programmer . Kuesioner yang diajukan menggunakan pengukuran skala likert yaitu skala 5 (Sugiyono, 2014). Skala yang diambil adalah sangat tidak menyukai, tidak menyukai, cukup menyukai, menyukai dan sangat menyukai. Beberapa skala yang lain adalah belum pernah sampai sangat sering dan tidak pernah menggunakan sampai sangat sering. Skala yang diambil sama yaitu skala satu sampai skala lima dengan semakin besarnya skala semakin bagus. Adapun responden yang diambil adalah 30 siswa SMK Nasional Malang. Adapun jumlah sampel yang digunakan disesuaikan dengan teori yang dikemukakan roscoe dalam bukunya Research Methods for Bussiness (1982:253) dalam metode penelitian pendidikan sugiyono

\section{Pelaksanaan Metode Pengabdian}

Adapun materi yang diberikan menggunakan software PROTO IO. Proto io merupakan Proto.io adalah web aplikasi yang sangat bagus untuk membuat prototipe desain, memiliki banyak fungsi. Anda bisa bekerja hanya dengan drag \& drop jika menggunakan aplikasi ini (Jurnal Web, 2015). Aplikasi ini berbasis web, namun Anda bisa menggunakannya juga di iOS dan Android. Berikut beberapa screenshoot penggunaan aplikasi Proto lo dalam pembuatan desain prototipe aplikasi. Contoh materi ditunjukkan pada Gambar 1 -Gambar 12.

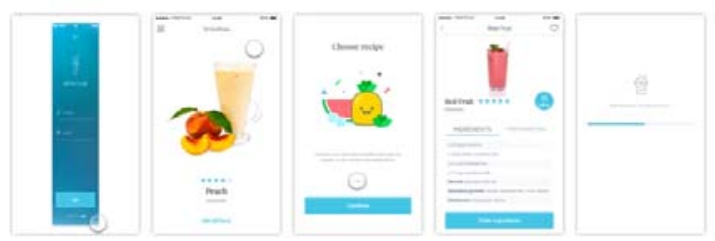

Gambar 1. Contoh Project yang Dibuat.

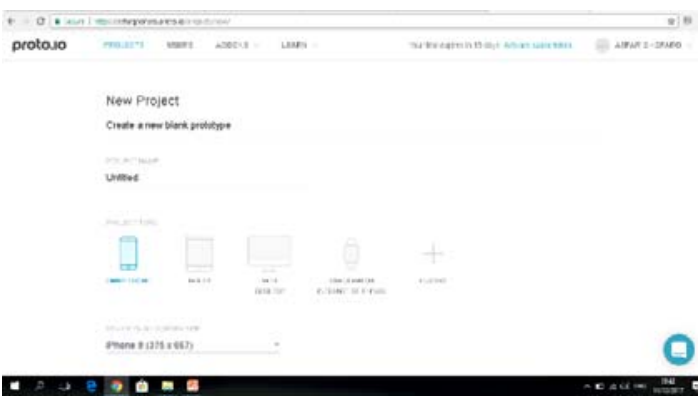

Gambar 2. Halaman Awal Pembuatan Project.

Pada Gambar 2 menunjukkan jenis device yang akan dibuat, dalam hal ini misalnya ada mobile, tablet, dan desktop.

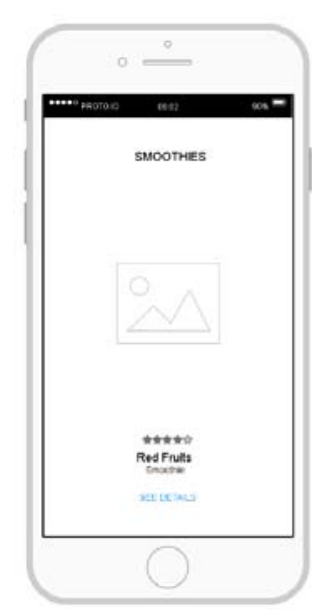

Gambar 3. Memasukkan Gambar dan Rating.
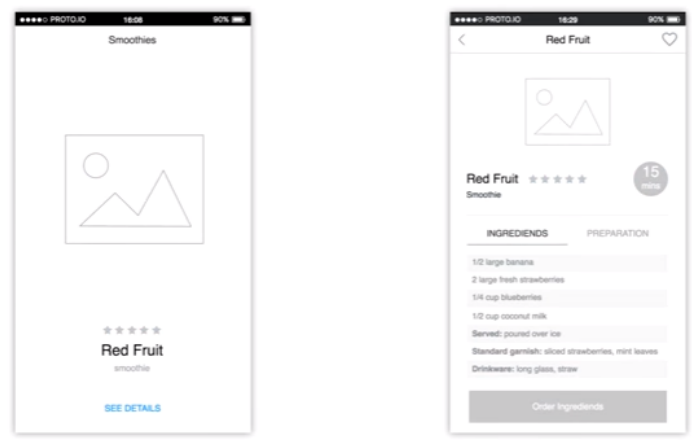

Gambar 4. Deskripsi dari Gambar. 


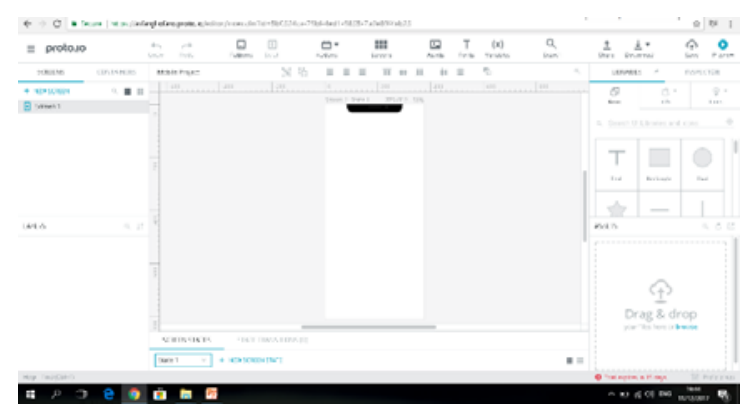

Gambar 5. Memulai Pembuatan Layout.

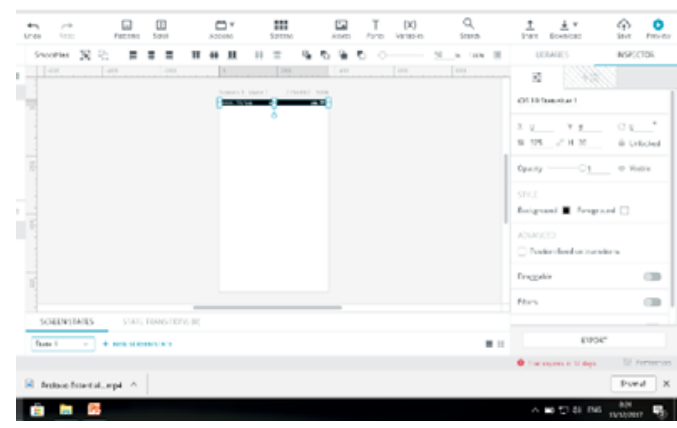

Gambar 6. Setting Layout untuk Notification.

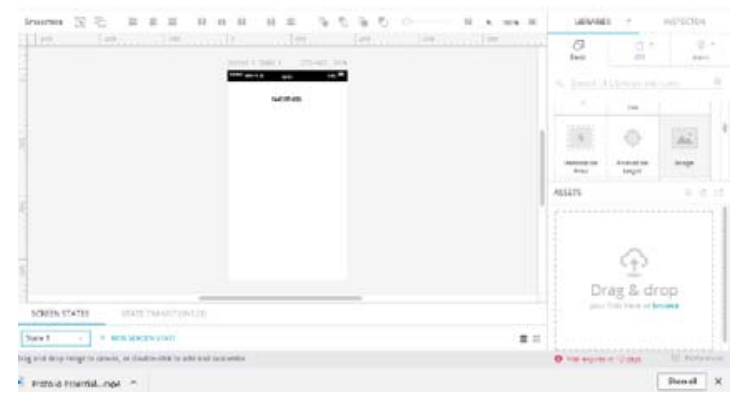

Gambar 7. Drag And Drop Object.

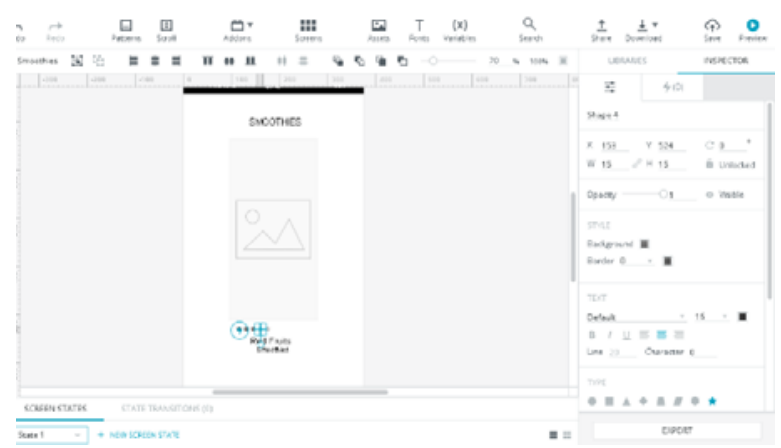

Gambar 8. Pembuatan Desain untuk Rating.

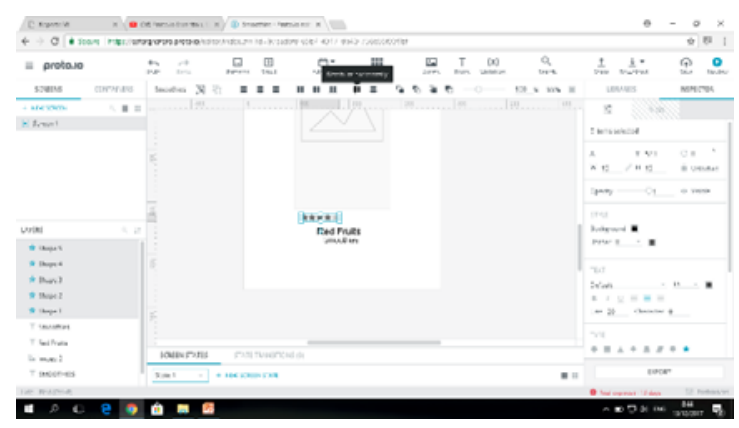

Gambar 9. Pembuatan Rating dan Deskripsi.

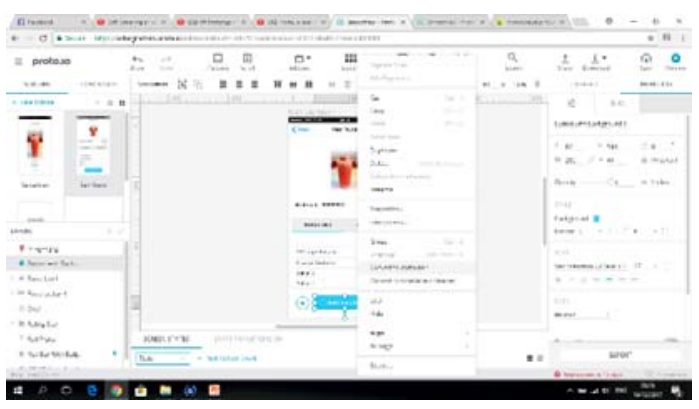

Gambar 10. Memasukkan Beberapa Komponen yang Dibutuhkan.

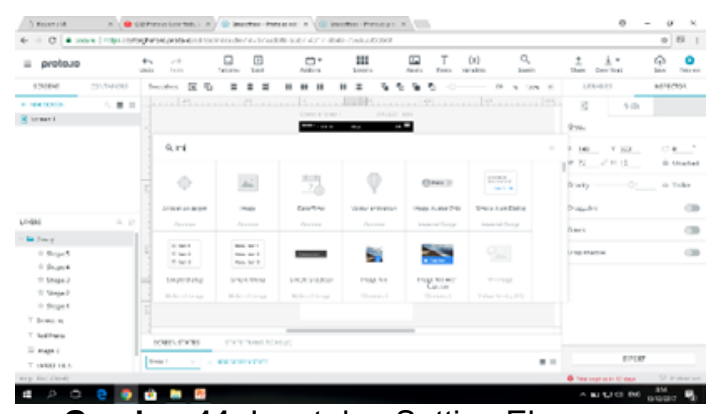

Gambar 11. Input dan Setting Elemen.

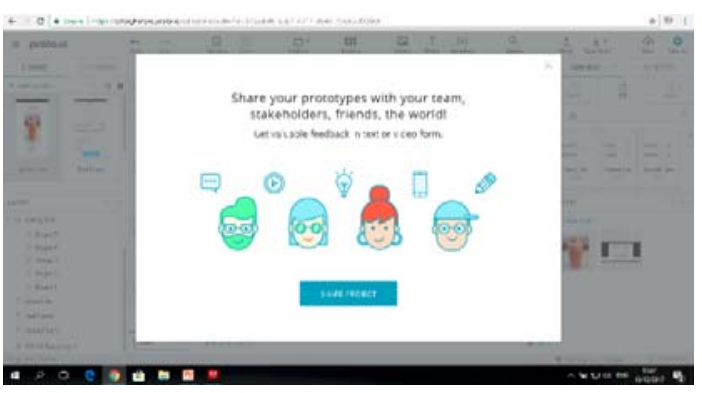

Gambar 12. Share Prototype yang sudah dibuat.

\section{Hasil Pengujian Kuesioner}

Hasil kuesioner sebelum pelatihan

Sebelum dilaksanakan pelatihan, pengabdi membagikan kuesioner pre-test untuk mengukur keadaan dan pola pikir siswa- 
siswi yang ada di SMK Nasional terhadap mata pelajaran pemrograman. Hasil kuesioner ditunjukkan pada table 3 sedangkan hasil pre test dalam bentuk diagram ditunjukkan pada gambar 13. Pada entitas skala terdiri dari skala 1-skala 5 dengan perbedaan warna ditunjukkan pada series 1 -series 5 .

Tabel 3. Hasil perhitungan kuesioner Pre Test.

\begin{tabular}{|r|r|r|r|r|r|r|r|}
\hline Skala & P1 & P2 & P3 & P4 & P5 & P6 & P7 \\
\hline 1 & 1 & 9 & 11 & 2 & 7 & 9 & 6 \\
\hline 2 & 4 & 6 & 5 & 1 & 8 & 8 & 12 \\
\hline 3 & 11 & 7 & 7 & 9 & 10 & 7 & 5 \\
\hline 4 & 12 & 5 & 4 & 12 & 2 & 4 & 3 \\
\hline 5 & 2 & 3 & 3 & 6 & 3 & 2 & 4 \\
\hline
\end{tabular}

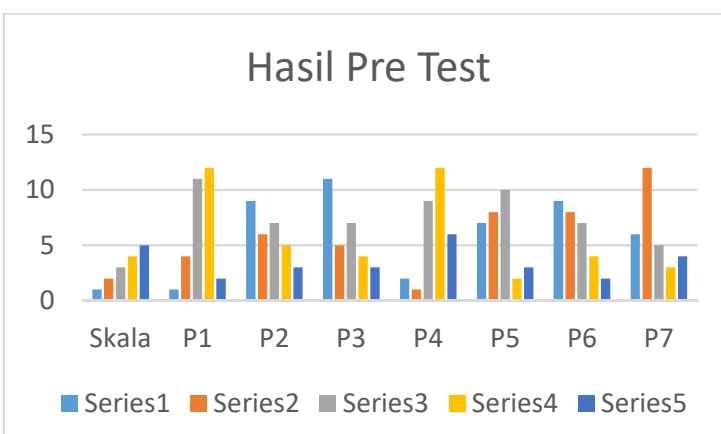

Gambar 13. Hasil Diagram Pre Test Sebelum Pelatihan.

Dari diagram pada gambar 13, pada pertanyaan 1 Menunjukkan bahwa minat menyukai siswa-siswi dalam mata pelajaran pemrograman dibagi menjadi tiga group yaitu tidak menyukai dengan menggabungkan prosentase skala 1 dan 2 sebesar 16,66\%, netral dengan skala 3 sebesar $36,66 \%$, dan menyukai dengan menggabungkan prosentase skala 4 dan 5 sebesar $46,66 \%$.

Dari diagram pada gambar 13, pada pertanyaan 2 Menunjukkan apakah mata pelajaran pemrograman mudah bagi mereka menjadi tiga group yaitu tidak mudah dengan menggabungkan prosentase skala 1 dan 2 sebesar $50 \%$, netral dengan skala 3 sebesar $23,33 \%$, dan mudah dengan menggabungkan prosentase skala 4 dan 5 sebesar 26,66\%.

Dari diagram pada gambar 13, pada pertanyaan 3 Menunjukkan kemudahan membuat aplikasi bagi mereka menjadi tiga group yaitu tidak mudah dengan menggabungkan prosentase skala 1 dan 2 sebesar $53,33 \%$, netral dengan skala 3 sebesar 23,33\%, dan mudah dengan menggabungkan prosentase skala 4 dan 5 sebesar $23,33 \%$.

Dari diagram pada gambar 13, pada pertanyaan 4 Menunjukkan keinginan menjadi programmer menjadi tiga group yaitu tidak menyukai dengan menggabungkan prosentase skala 1 dan 2 sebesar $10 \%$, netral dengan skala 3 sebesar $30 \%$, dan menyukai dengan menggabungkan prosentase skala 4 dan 5 sebesar $60 \%$.

Dari diagram pada gambar 13, pada pertanyaan 5 Menunjukkan pengetahuan mereka tentang banyaknya software instan untuk membuat prototype suatu aplikasi menjadi tiga group yaitu tidak tahu dengan menggabungkan prosentase skala 1 dan 2 sebesar $50 \%$, netral dengan skala 3 sebesar $33,33 \%$, dan tahu dengan menggabungkan prosentase skala 4 dan 5 sebesar $16,66 \%$.

Dari diagram pada gambar 13, pada pertanyaan 6 Menunjukkan apakah mereka sudah pernah membuat prototype online maupun offline menjadi tiga group yaitu tidak pernah dengan menggabungkan prosentase skala 1 dan 2 sebesar 56,66\%, kadangkadang dengan skala 3 sebesar $23,33 \%$, dan sering dengan menggabungkan prosentase skala 4 dan 5 sebesar $20 \%$.

Dari diagram pada gambar 13 , pada pertanyaan 7 Menunjukkan penggunaan software prototype online maupun offline dalam membuat desain aplikasi dibagi menjadi tiga group yaitu tidak menyukai dengan menggabungkan prosentase skala 1 dan 2 sebesar $60 \%$, netral dengan skala 3 sebesar $16,66 \%$, dan menyukai dengan menggabungkan prosentase skala 4 dan 5 sebesar $23,33 \%$.

\section{Hasil kuesioner setelah pelatihan}

Tabel 4. Hasil perhitungan kuesioner Post Test

\begin{tabular}{|r|r|r|r|r|r|r|r|r|}
\hline Skala & P1 & P2 & P3 & P4 & P5 & P6 & P7 & P8 \\
\hline 1 & 0 & 0 & 1 & 0 & 0 & 1 & 1 & 1 \\
\hline 2 & 1 & 2 & 4 & 1 & 0 & 2 & 2 & 1 \\
\hline 3 & 8 & 5 & 7 & 4 & 2 & 6 & 3 & 5 \\
\hline 4 & 12 & 8 & 10 & 11 & 12 & 8 & 13 & 8 \\
\hline 5 & 9 & 15 & 8 & 14 & 16 & 13 & 11 & 15 \\
\hline
\end{tabular}

Dari diagram pada gambar 14, pada pertanyaan 1 Menunjukkan kegunaan pelatihan yang dilakukan menjadi tiga group yaitu tidak menyukai dengan menggabungkan prosentase skala 1 dan 2 sebesar 3,33\%, netral dengan skala 3 sebesar $26,66 \%$, dan 
menyukai dengan menggabungkan prosentase skala 4 dan 5 sebesar $70 \%$.

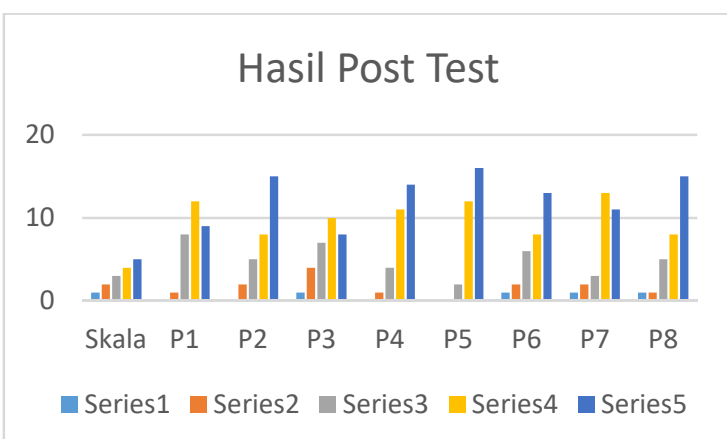

Gambar 14. Hasil Diagram Post Test Setelah Pelatihan.

Dari diagram pada gambar 14, pada pertanyaan 2 Menunjukkan dampak pelatihan menjadi tiga group yaitu tidak menyukai dengan menggabungkan prosentase skala 1 dan 2 sebesar $6,66 \%$, netral dengan skala 3 sebesar $16,66 \%$, dan menyukai dengan menggabungkan prosentase skala 4 dan 5 sebesar $76,66 \%$.

Dari diagram pada gambar 13, pada pertanyaan 3 Menunjukkan apakah materi yang diberikan mudah bagi mereka menjadi tiga group yaitu tidak menyukai dengan menggabungkan prosentase skala 1 dan 2 sebesar $16,66 \%$, netral dengan skala 3 sebesar 23,33\%, dan menyukai dengan menggabungkan prosentase skala 4 dan 5 sebesar $60 \%$.

Dari diagram pada gambar 13, pada pertanyaan 4 Menunjukkan apakah tema materi yang diberikan menarik menjadi tiga group yaitu tidak menyukai dengan menggabungkan prosentase skala 1 dan 2 sebesar 3,33\%, netral dengan skala 3 sebesar $13,33 \%$, dan menyukai dengan menggabungkan prosentase skala 4 dan 5 sebesar $83,33 \%$.

Dari diagram pada gambar 13, pada pertanyaan 5 Menunjukkan apakah user interface aplikasi yang dibuat dengan software proto io menarik bagi mereka menjadi tiga group yaitu tidak menyukai dengan menggabungkan prosentase skala 1 dan 2 sebesar $0 \%$, netral dengan skala 3 sebesar $6,66 \%$, dan menyukai dengan menggabungkan prosentase skala 4 dan 5 sebesar $93,33 \%$.

Dari diagram pada gambar 13, pada pertanyaan 6 Menunjukkan Apakah dengan membuat prototipe melalui aplikasi instan (contoh: Proto lo) membuat mereka ingin membuat aplikasi tersebut benar-benar berfungsi (aplikasi yang dibuat melalui Proto lo hanya desain interface aplikasi namun belum berfungsi secara pemrograman) menjadi tiga group yaitu tidak menyukai dengan menggabungkan prosentase skala 1 dan 2 sebesar $10 \%$, netral dengan skala 3 sebesar $20 \%$, dan menyukai dengan menggabungkan prosentase skala 4 dan 5 sebesar $70 \%$.

Dari diagram pada gambar 13, pada pertanyaan 7 Menunjukkan keinginan/ motivasi mereka dalam belajar pemrograman agar bias membuat aplikais menjadi tiga group yaitu tidak menyukai dengan menggabungkan prosentase skala 1 dan 2 sebesar $10 \%$, netral dengan skala 3 sebesar $10 \%$, dan menyukai dengan menggabungkan prosentase skala 4 dan 5 sebesar $80 \%$.

Dari diagram pada gambar 13 , pada pertanyaan 8 Menunjukkan minat mereka menjadi seorang programmer menjadi tiga group yaitu tidak menyukai dengan menggabungkan prosentase skala 1 dan 2 sebesar $6,66 \%$, netral dengan skala 3 sebesar $16,66 \%$, dan menyukai dengan menggabungkan prosentase skala 4 dan 5 sebesar $76,66 \%$.

Adapun signifikansi perubahan bisa dilihat antara pertanyaan pre-test pertama yaitu apakah mereka menyukai mata pelajaran pemrograman sebesar 3,33\% dan pertanyaan post test ketujuh tentang keinginan belajar pemrograman lebih lanjut sebesar $80 \%$. Hal ini menunjukkan perubahan yang sangat signifikan yaitu 76,67 . Perubahan cukup signifikan juga bisa dilihat dari pertanyaan pre test keempat dan pertanyaan post test ke 8 yaitu keinginan menjadi programmer. Hasil pre test menunjukkan $60 \%$ dan Post test $76,66 \%$. Hal ini menunjukkan peningkatan sebesar $16,66 \%$.

\section{Dokumentasi Pelaksanaan}

Adapun beberapa dokumentasi kegiatan yang dilakukan dilihat pada gambar 15-gambar 16 


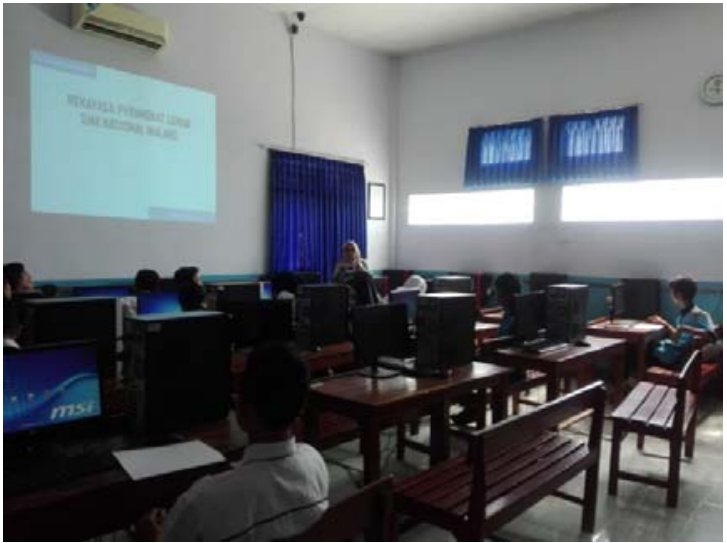

Gambar 15. Dokumentasi kedua.

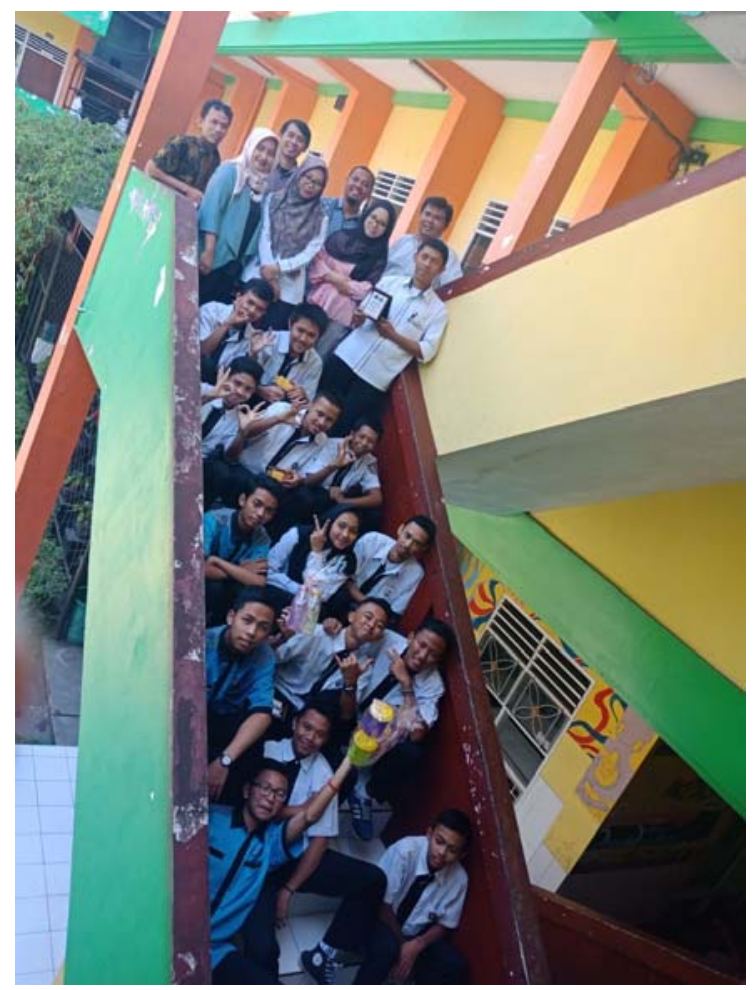

Gambar 16. Dokumentasi pertama

\section{SIMPULAN DAN SARAN}

Dari hasil pelatihan dan pengujian pola fikir siswa-siswi SMK Nasional dalam menghadapi mata pelajaran pemrograman dengan mengajarkan mereka hasil output aplikasi dengan perancangan prototipe menggunakan software instan PROTO IO meningkatkan motivasi minat mereka belajar pemrograman secara signifikan sebesar $76,67 \%$. Dalam analisis hasil kuesioner tidak mempertimbangkan jawaban responden yang memilih skala 3 atau netral. Ada dua kelompok besar yang diklasifikasikan yaitu adanya ketidakmauan belajar(skala 1 dan 2) dan kemauan peningkatan belajar pemrograman(skala 4 dan 5). Hal ini cukup berpengaruh dalam pembelajaran dan diperlukan penelitian lebih lanjut melalui penelitian lanjutan berupa wawancara untuk mengetahui alas an lebih dalam mereka berada diposisi mana.

\section{DAFTAR RUJUKAN}

KEMENRISTEKDIKTI. Keputusan Menteri Riset, Teknologi, dan Pendidikan Tinggi Republik Indonesia, No 257/M/Kpt/2017 $\S(2017)$. https://doi.org/10.1007/s11606010-1529-0

Sugiyono. (2014). Metode Penelitian Pendidikan Pendekatan Kuantitatif, Kualitatif, dan R\&D. Bandung: Alfabeta.

Web, J. (2015). 5 Alat Untuk Membuat Prototipe Desain. Retrieved February 2, 2019, from https://www.jurnalweb.com/5alat-untuk-membuat-prototipe-desain/ 